Reprinted with permission from: Weed Technology. 1997. 11(4):787-792.

Published and copyrighted by: Weed Science Society of America, http://www.wssa.net

\title{
Competitive grasses for leafy spurge (Euphorbia esula) reduction
}

\author{
RODNEY G. LYM and DWIGHT A. TOBER
}

Professor, Plant Science Department, North Dakota State University, Fargo, ND 58105, and Plant Materials Center Manager, U.S. Department of Agriculture, Natural Resource Conservation Service (USDA NRCS), Bismarck, ND 58504 .

\begin{abstract}
:
Twelve grass genotypes were evaluated for competitiveness with leafy spurge and herbage yield in two sites in North Dakota. 'Rebound' smooth brome, 'Rodan' western wheatgrass, 'Bozoisky' Russian wildrye, and 'Arthur' Dahurian wildrye reduced leafy spurge stem density an average of $63 \%$ after 3 years in a silty clay soil at Fargo. 'Reliant' intermediate wheatgrass reduced leafy spurge stem density every year for 3 years, including an $85 \%$ reduction the second year after planting, and consistently produced high herbage yields. Rebound smooth brome and Reliant intermediate wheatgrass averaged 72\% leafy spurge reduction 3 years after seeding in a loamy sand soil at Jamestown. Reliant intermediate wheatgrass and 'Manska' pubescent wheatgrass provided the most consistent herbage production, which averaged about $2,000 \mathrm{~kg} / \mathrm{ha}$ annually for 3 years.
\end{abstract}

\section{Nomenclature:}

Smooth brome, Bromus inermis Leyss; western wheatgrass, Pascopyron smithii (Rydb.) A. Love; Russian wildrye and Dahurian wildrye, Psathyrostachys juncea (Fisch.) Nevski.; Dahurian wildrye, Elymus dahuricus Turcz;; intermediate and pubescent wheatgrass, Elytrigia intermedia (Host) Nevski, leafy spurge, Euphorbia esula L. \#² EPHES.

\footnotetext{
${ }^{1}$ Received for publication April 4, 1997, and in revised form August 25, 1997.

${ }^{2}$ Letters following this symbol are a WSSA-approved computer code from Composite List of Weeds, Revised 1989. Available from WSSA, 810 East 10th Street, Lawrence, KS 66044-8897.
} 


\section{Additional index words:}

Rangeland weed control, integrated plant management, cultural control, integrated control.

\section{Introduction}

Traditionally, herbicides have been use to control leafy spurge and have been relatively successful when a long-term program is followed (Lorenz and Lym 1993). However, herbicides are not always acceptable due to their cost, potential for groundwater contamination, and prohibition in environmentally sensitive areas. Consequently, nonchemical methods for leafy spurge control must be established.

Nontraditional methods to control leafy spurge include biocontrol with insects, grazing with sheep or goats, cultivation, and plant competition (Lym 1994). Grass competition has long been recognized as a method of leafy spurge control. Crested wheatgrass [Agropyron cristatum (L.) Gaertn.] ${ }^{3}$ decreased the rate of vegetative spread, limited density, reduced seed production, and suppressed top growth of leafy spurge in Saskatchewan (Selleck et al. 1962). Competition from crested wheatgrass along with 2,4-D [(2,4-dichlorophenoxy)acetic acid] applied twice per year resulted in leafy spurge root eradication after 3 years (Selleck et al. 1962). 'Luna' pubescent wheatgrass and 'Bozoisky' Russian wildrye reduced leafy spurge by over $90 \%$ for at least 3 years in Wyoming (Ferrell et al. 1993).

The most competitive grass genotypes against leafy spurge vary by region. For example, several grass species were evaluated in Minnesota for controlling leafy spurge, including mixtures of three varieties of wheatgrass, three varieties of brome, and mixtures of native species including big bluestem (Andropogon gerardii Vitman) and little bluestem (Schizachyrium scoparium (Michx.) Nash] (Biesboer et al. 1993). All treatments that contained little bluestem established well and reduced leafy spurge infestations. Unlike in Wyoming, Luna pubescent wheatgrass and Bozoisky Russian wildrye were among the least effective grasses evaluated in Minnesota (D. D. Biesboer, personal communication). The most competitive grasses against leafy spurge in Montana were crested wheatgrass and intermediate wheatgrass (Wallander and Olson 1995).

Herbicide and fertilizer treatments have been combined with competitive grasses to enhance and/or maintain long-term control. Herbicides applied to established grasses increased leafy spurge control in Minnesota (Biesboer et al. 1993). In Wyoming, glyphosate $[N($ phosphonomethyl $)$ glycine] was applied prior to grass seeding to reduce the leafy spurge stand and enhance establishment (Ferrell et al. 1992). Nitrogen and phospho-

\footnotetext{
${ }^{3}$ Nomenclature follows USDA, NRCS, 1997. The PLANTS database. National Plant Data Center, Baton Rouge, LA $70874-4490$
} 
rus were applied to several grass species in Montana to increase control, but had little effect (Wallander and Olson 1995).

An ideal grass species for leafy spurge control should provide good yields and high nutrient content as well as vigorous competition against the weed. The purpose of this study was to evaluate various grass genotypes for competitiveness with leafy spurge and herbage yield at two locations in North Dakota with different soil types.

\section{Materials and Methods}

Fargo. The first experiment was established in a dense stand of leafy spurge (160 stems $/ \mathrm{m}^{2}$ ) on the North Dakota State University experiment station at Fargo. The soil was a Fargo silty clay (fine, montmorillonitic, frigid, Vertic Haplaquolls; 3.5\% organic matter and $\mathrm{pH}$ 8.0). Plots were 3.5 by $13.5 \mathrm{~m}$, and treatments were replicated four times in a completely random design. Initial leafy spurge stand counts were recorded on May 23, 1990 , by counting the number of stems in eight $0.25-\mathrm{m}^{2}$ quadrats per plot. Leafy spurge top growth was reduced by glyphosate plus 2,4-D at 0.4 plus $0.65 \mathrm{~kg}$ ae/ha applied over the entire study on May 23, 1990, when leafy spurge was in the flowering growth stage and again on July 27, 1990, to leafy spurge regrowth. The herbicide treatments reduced the leafy spurge top growth to allow adequate seedbed preparation and reduce initial leafy spurge competition for better seedling establishment (Ferrell et al. 1992). Herbicides were applied using a tractor-mounted sprayer delivering $80 \mathrm{~L} / \mathrm{ha}$.

The seedbed was prepared by cultivation on August 6 and 28, 1990. The soil was cultivated to a $15-\mathrm{cm}$ depth using a field cultivator with $18-\mathrm{cm}$-wide shovel sweeps. There were four passes (two forward and two back) during the initial cultivation. Plant residue on the soil surface was removed from the plots because trash interfered with the small plot seeder. The grasses were seeded with an eight-row 1.8-m-wide coneseeder with a $20-\mathrm{cm}$ row spacing on August 29, 1990. Seeding rate varied by genotypes as recommended by USDA NRCS technical guide standards (Table 1). The experimental site was irrigated with $2.5 \mathrm{~cm}$ of water per time on September 13 and 25, 1990, and $3.2 \mathrm{~cm}$ of rain fell on October 7.

Bromoxynil (3,5-dibromo-4-hydroxybenzonitrile) plus 2,4-D at 0.28 ai plus $0.84 \mathrm{~kg}$ ae/ha were applied in May 1991 to control annual broadleaf weeds and allow the grasses to establish better. Thereafter, one herbicide-only treatment of glyphosate plus 2,4-D at 0.4 plus $0.65 \mathrm{~kg} / \mathrm{ha}$ applied annually in September was included as a standard for leafy spurge control. Leafy spurge density was recorded in late May annually from 1991 through 1993 at approximately the same location within a plot as the initial evaluation in 1990. The plots were harvested annually in mid-July of 1991 through 1993 by clipping four $0.25-\mathrm{m}^{2}$ quadrats per plot. Herbage was separated into seeded grass, weedy grass species, leafy spurge, and forbs, and then oven dried at $60 \mathrm{C}$. Herbage data are reported on a dry weight basis.

Page 3 of 10 
Table 1. Pure live seed percentages and seeding rate of grass genotypes in the two soil types (experiment locations) in North Dakota.

\begin{tabular}{|c|c|c|c|c|}
\hline & \multicolumn{2}{|c|}{ Pure live seeds } & \multicolumn{2}{|c|}{ Location } \\
\hline \multirow[t]{2}{*}{ Grass genotypes and cultivar } & Silty clay & Loamy sand & Silty clay & $\overline{\text { Loamy sand }}$ \\
\hline & \multicolumn{2}{|c|}{ - } & \multicolumn{2}{|c|}{$\begin{array}{l}\text { Pure live } \\
- \text {-seeds } / \mathrm{m}^{2}\end{array}$} \\
\hline 'Rebound' smooth brome & 84 & 76 & 205 & 310 \\
\hline 'Rodan' western wheatgrass & 81 & 88 & 270 & 400 \\
\hline 'Bozoisky' Russian wildrye & 92 & 94 & 280 & 420 \\
\hline 'Arthur' Dahurian wildrye & 93 & 93 & 180 & 270 \\
\hline 'Reliant' intermediate wheatgrass & 87 & 84 & 180 & 270 \\
\hline T-17596 mountain rye & 70 & - & 180 & - \\
\hline 'Hycrest' crested wheatgrass & 90 & 87 & 260 & 390 \\
\hline 'Killdeer' sideoats grama & 70 & - & 330 & - \\
\hline 'Mankota' Russian wildrye & - & 86 & - & 420 \\
\hline 'Pryor' slender wheatgrass & - & 52 & - & 380 \\
\hline 'Lodorm' green needlegrass & - & 96 & - & 480 \\
\hline 'Manska' pubescent wheatgrass & - & 93 & - & 270 \\
\hline
\end{tabular}

Jamestown. A second experiment was established near the Pipestem dam located approximately $10 \mathrm{~km}$ north of Jamestown, ND, to evaluate competitive grass genotypes in a soil type more typical of North Dakota than Fargo clay. The soil at Jamestown was a Fordville loamy sand (fine-loamy over sandy or sandy skeletal, mixed Pachic Udic Haploborolls; $6.8 \%$ organic matter and $\mathrm{pH} 6.8$ ). The experimental design and plot size were the same as at Fargo. Vegetation at the site was predominantly Kentucky bluegrass (Poa pratensis L.) sod. The initial leafy spurge stand counts on May 26, 1993, averaged 83 stems $/ \mathrm{m}^{2}$. Glyphosate plus 2,4-D at 0.4 plus $0.65 \mathrm{~kg} / \mathrm{ha}$ was applied in June and again in July 1993 as for the first experiment. The seedbed was prepared and the grasses were seeded on August 24, 1993 (Table 1). The seeding rate was increased compared to the Fargo site to allow for some loss of seeds in the drill mechanisms. No irrigation was necessary, as the soil moisture was high at seeding and $1.25 \mathrm{~cm}$ of rain was received each week for the next 3 weeks.

The grass genotypes seeded at Jamestown were similar to Fargo, except 'Killdeer' sideoats grama [Bouteloua curtipendula (Michx.) Torr.] and T-17596 mountain rye (Secale montanum Guss.) were not used. Also, 'Pryor' slender wheatgrass (Elymus trachycaulus (Link) Gould ex Shinners], 'Lodorm' green needlegrass [Nasella viridula (Trin.) Barkworth], Manska pubescent wheatgrass, and 'Mankota' Russian wildrye were added to the study. The plots were harvested in mid-July of 1994 through 1996, and herbage was separated and evaluated as previously described.

The experiments were a completely random design, and data were subjected to analyses of variance using the general linear models procedure and the protected LSD mean separation technique. Because the experiments were established at separate locations in different years, the results are reported separately. 


\section{Results and Discussion}

Fargo. All grasses seeded at Fargo were competitive against leafy spurge, except Killdeer sideoats grama, which did not establish (Table 2). Arthur Dahurian wildrye, Bozoisky Russian wildrye, 'Hycrest' crested wheatgass, and Reliant intermediate wheatgrass established rapidly despite the dry conditions during and after seeding in 1990 (data not shown).

Leafy spurge stem density tended to be similar or to increase from 1990 to 1991 regardless of treatment (Table 2). For example, leafy spurge density in the untreated control increased from $160 \mathrm{stems} / \mathrm{m}^{2}$ in 1990 to $380 \mathrm{stems} / \mathrm{m}^{2}$ in 1991 . The increase was likely due to cultivation prior to seeding, which broke apical dominance and caused many root buds to begin growth. Despite the overall increase, leafy spurge density in the seeded grasses was lower than in the control except for three treatments. Thus, most of the seeded grasses were competitive with leafy spurge even in the first year of establishment.

All established grasses reduced leafy spurge density in 1992, the second year after seeding (Table 2). The greatest stem density reduction occurred with Rebound smooth brome, Rodan western wheatgrass, Bozoisky Russian wildrye, and Arthur Dahurian wildrye, which averaged $105 \mathrm{stems} / \mathrm{m}^{2}$ or less compared to $260 \mathrm{stems} / \mathrm{m}^{2}$ in the control.

Table 2. Evaluation of various grass genotypes for reduction of leafy spurge in a silty clay soil at Fargo. ND.

Leafy spurge stems ${ }^{\mathrm{a}}$

\begin{tabular}{lccccc}
\cline { 2 - 4 } Grass genotypes or herbicide treatment & 1990 & 1991 & 1992 & 1993 & \\
\hline & ---- & & $1993^{\mathrm{b}}$ \\
\hline & 180 & 220 & 80 & 60 & 63 \\
Rebound smooth brome & 160 & 280 & 120 & 60 & 63 \\
Rodan western wheatgrass & 160 & 240 & 100 & 60 & 63 \\
Bozoisky Russian wildrye & 180 & 280 & 120 & 80 & 50 \\
Arthur Dahurian wildrye & 160 & 200 & 140 & 120 & 25 \\
Reliant intermediate wheatgrass & 160 & 200 & 140 & 120 & 25 \\
T-17596 mountain rye & 180 & 180 & 140 & 100 & 38 \\
Hycrest crested wheatgrass & 160 & 280 & - & - & - \\
Killdeer sideoats grama & 160 & 180 & 4 & 4 & 98 \\
Glyphosate $+2,4-\mathrm{D}$, & 160 & 380 & 260 & 160 & \\
Control & NS & 99 & 48 & 47 & 16 \\
LSD $(0.05)$ & & & & & \\
\hline
\end{tabular}

${ }^{\mathrm{a}}$ Mean of four $0.25-\mathrm{m}^{2}$ quadrats counted per plot in May of each year.

${ }^{\mathrm{b}}$ Change in leafy spurge stand count in 1993 compared to the control.

${ }^{c}$ Glyphosate + 2,4-D at $0.4+0.65 \mathrm{~kg} / \mathrm{ha}$ was annually applied in September 1990, 1991, and 1992.

Leafy spurge stem density tended to decrease with all established grasses in 1993, 3 years after seeding (Table 2). The grasses that resulted in the greatest reduction in stem density continued to be Rebound smooth brome, Rodan western wheatgrass, Bozoisky 
Russian wildrye, and Arthur Dahurian wildrye; these treatments averaged $60 \%$ stem reduction.

Grass genotypes that provided the greatest reduction in leafy spurge did not necessarily provide the largest herbage yield. For example, Rebound smooth brome and Rodan western wheatgrass averaged over 3,400 kg/ha yield in 1992 compared to only 1,420 $\mathrm{kg} /$ ha for Bozoisky Russian wildrye (Table 3), even though all reduced leafy spurge stem density approximately $60 \%$ (Table 2 ). Rodan western wheatgrass and Reliant intermediate wheatgrass tended to yield the highest annual herbage production, averaging 2,360 $\mathrm{kg} /$ ha over the 3 years evaluated (Table 3 ).

Table 3. Herbage and leafy spurge yield at Fargo, ND.

\begin{tabular}{|c|c|c|c|c|c|c|c|c|c|c|c|c|}
\hline \multicolumn{13}{|c|}{ Yield $^{\mathrm{a}}$} \\
\hline \multirow{2}{*}{$\begin{array}{l}\text { Grass genotypes or } \\
\text { herbicide treatment }\end{array}$} & \multicolumn{3}{|c|}{ Grass } & \multicolumn{3}{|c|}{ Leafy spurge } & \multicolumn{3}{|c|}{ Total $^{\mathrm{b}}$} & \multicolumn{3}{|c|}{$\begin{array}{c}\text { Proportion } \\
\text { leafy spurge }\end{array}$} \\
\hline & 1991 & 1992 & 1993 & 1991 & 1992 & 1993 & 1991 & 1992 & 1993 & 1991 & 1992 & 1993 \\
\hline & \multicolumn{9}{|c|}{-------------------------------kg/ha------------------------------ } & \multicolumn{3}{|c|}{ 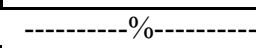 } \\
\hline Rebound smooth brome & 570 & 3,450 & 2,375 & 330 & 50 & 215 & 2,285 & 3,560 & 2,710 & 14 & 2 & 8 \\
\hline $\begin{array}{c}\text { Rodan western } \\
\text { wheatgrass }\end{array}$ & 1,060 & 3,665 & 2,880 & 305 & 160 & 680 & 2,235 & 3,860 & 3,675 & 14 & 4 & 18 \\
\hline $\begin{array}{l}\text { Bozoisky Russian } \\
\text { wildrye }\end{array}$ & 720 & 1,420 & 1,320 & 260 & 105 & 500 & 2,150 & 1,830 & 1,980 & 12 & 8 & 25 \\
\hline $\begin{array}{l}\text { Arthur Dahurian } \\
\text { wildrye }\end{array}$ & 1,325 & 3,645 & 1,575 & 245 & 70 & 655 & 2,295 & 3,760 & 2,755 & 11 & 2 & 24 \\
\hline $\begin{array}{l}\text { Reliant intermediate } \\
\text { wheatgrass }\end{array}$ & 2,575 & 2,450 & 1,770 & 240 & 40 & 240 & 3,030 & 2,495 & 2,185 & 8 & 2 & 11 \\
\hline $\mathrm{T}-17596$ mountain rye & 400 & 280 & 460 & 160 & 145 & 640 & 2,015 & 930 & 1,670 & 8 & 16 & 38 \\
\hline $\begin{array}{l}\text { Hycrest crested } \\
\text { wheatgrass }\end{array}$ & 1,240 & 1,955 & 1,190 & 235 & 110 & 440 & 2,330 & 2,175 & 2,030 & 10 & 5 & 22 \\
\hline $\begin{array}{l}\text { Killdeer sideoats } \\
\text { grama }^{\mathrm{d}}\end{array}$ & 1 & - & - & 360 & - & - & 2,250 & - & - & 16 & - & - \\
\hline Glyphosate $+2,4-D^{\mathrm{e}}$ & 0 & 0 & 0 & 565 & 10 & 15 & 2,675 & 1,240 & 1,140 & 21 & 1 & 1 \\
\hline Control & 0 & 0 & 0 & 565 & 265 & 710 & 1,495 & 1,085 & 1,660 & 38 & 24 & 43 \\
\hline $\operatorname{LSD}(0.05)$ & 864 & 1,593 & 1,189 & $248^{\mathrm{f}}$ & 97 & 360 & NS & 1,595 & 1,245 & 17 & 8 & 15 \\
\hline
\end{tabular}

${ }^{\mathrm{a}}$ Four $0.25-\mathrm{m}^{2}$ quadrats harvested per plot in July each year.

${ }^{\mathrm{b}}$ Total yield includes weedy grasses and other forbs.

${ }^{c}$ Percent of component in total yield.

${ }^{\mathrm{d}}$ Killdeer sideoats grama did not establish and was not evaluated after 1991.

${ }^{\mathrm{e}}$ Glyphosate +2,4-D at $0.4+0.65 \mathrm{~kg} / \mathrm{ha}$ was applied annually in September 1990, 1991, 1992, and 1993. ${ }^{\mathrm{f}} \mathrm{LSD}=0.10$.

Reliant intermediate wheatgrass may be the best grass to seed for leafy spurge control in a North Dakota silty clay soil. This grass was competitive with leafy spurge almost immediately, reduced the proportion of the weed to $8 \%$ the first year after seeding, consistently produced high yields (Table 3 ), and was among the best at maintaining reduced leafy spurge stem densities (Table 2).

Reliant intermediate wheatgrass and Rebound smooth brome are introduced grasses that appear to provide at least short-term leafy spurge reduction and good herbage yield. Both provide high quality herbage for pasture or hay. Rodan western wheatgrass is a native grass with longer term survival, and it would be especially useful when included as 
part of a mixture of other native genotypes adapted to the site. Planting mixed species that are competitive with leafy spurge rather than a single species would be desirable for rangeland seeding. The mixed species would likely do well compared to a single species on a variety of soil types, terrains, and grazing management programs.

The glyphosate plus 2,4-D treatment reduced leafy spurge yield the most, with only 10 and $15 \mathrm{~kg} / \mathrm{ha}$ in 1992 and 1993, respectively, compared to 265 and $710 \mathrm{~kg} / \mathrm{ha}$ in the control for the same years (Table 3). Even though three annual treatments of glyphosate plus 2,4-D reduced leafy spurge top growth to near zero, total herbage yield was similar to the control because many annual weeds germinated each spring. This annual treatment would be useful for reducing leafy spurge in minimum or no-till cropland, but it would be impractical for pasture and rangeland.

Jamestown. All grass treatments except Lodorm green needlegrass reduced leafy spurge density compared to the untreated control in the sandy loam soil at Jamestown in 1994 the first year after seeding (Table 4). The greatest reduction averaged $35 \mathrm{stems} / \mathrm{m}^{2}$

Table 4. Evaluation of various grass genotypes for reduction of leafy spurge on a loamy sand soil near Jamestown, ND.

\begin{tabular}{|c|c|c|c|c|c|}
\hline \multirow{2}{*}{$\begin{array}{l}\text { Grass genotypes or } \\
\text { herbicide treatment }\end{array}$} & \multicolumn{4}{|c|}{ Leafy spurge stand count ${ }^{\mathrm{a}}$} & \multirow{2}{*}{$\begin{array}{c}\text { Leafy spurge } \\
\text { reduction in } \\
1996^{\mathrm{b}}\end{array}$} \\
\hline & 1993 & 1994 & 1995 & 1996 & \\
\hline & \multicolumn{4}{|c|}{ 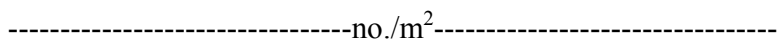 } & --------\%------- \\
\hline Rebound smooth brome & 60 & 56 & 12 & 32 & 76 \\
\hline Rodan western Wheatgrass & 132 & 64 & 44 & 60 & 55 \\
\hline Bozoisky Russian Wildrye & 80 & 52 & 40 & 64 & 50 \\
\hline Arthur Dahurian wildrye & 64 & 36 & 20 & 44 & 67 \\
\hline Mankota Russian wildrye & 68 & 48 & 44 & 66 & 58 \\
\hline Reliant intermediate wheatgrass & 80 & 36 & 28 & 44 & 67 \\
\hline Hycrest crested wheatgrass & 84 & 48 & 48 & 60 & 55 \\
\hline Pryor slender Wheatgrass & 96 & 44 & 36 & 80 & 39 \\
\hline Lodorm green needlegrass & 112 & 80 & 52 & 80 & 39 \\
\hline Manska pubescent wheatgrass & 72 & 24 & 36 & 60 & 55 \\
\hline Glyphosate $+2,4-\mathrm{D}^{\mathrm{c}}$ & 64 & 80 & 8 & 28 & 79 \\
\hline Control & 92 & 88 & 124 & 132 & \\
\hline $\operatorname{LSD}(0.05)$ & NS & 19 & 20 & 24 & 18 \\
\hline
\end{tabular}

${ }^{\mathrm{a}}$ Mean of four $0.25-\mathrm{m}^{2}$ quadrats counted per plot in May of each year.

${ }^{\mathrm{b}}$ Change in leafy spurge stand count in 1996 compared to the control.

'Glyphosate + 2,4-D was annually applied at $0.4+0.65 \mathrm{~kg} / \mathrm{ha}$ in June 1993, 1994, and 1995 .

(60\% control) from four seeded grasses-Arthur Dahurian wildrye, Reliant intermediate wheatgrass, Pryor slender wheatgrass, and Manska pubescent wheatgrass. The increase in competition at Jamestown compared to Fargo likely was due to the ideal soil moisture 
and timely rains before and after seeding $(1.25 \mathrm{~cm}$ of rain each week for the first 3 weeks after seeding).

All grasses seeded at Jamestown reduced leafy spurge density the second and third years after seeding (Table 4). The highest leafy spurge reduction by a grass was $76 \%$ by Rebound smooth brome when the study was concluded in 1996. This was comparable to the $79 \%$ leafy spurge reduction provided by the glyphosate plus 2,4-D annual treatment. Another indicator of the high competitiveness of the grass treatments was the very low leafy spurge yield in 1994, which averaged $20 \mathrm{~kg} /$ ha or less with most seeded grass treatments compared to $230 \mathrm{~kg} / \mathrm{ha}$ in the control (Table 5).

Table 5. Herbage and leafy spurge yield at Jamestown. ND.

\begin{tabular}{|c|c|c|c|c|c|c|c|c|c|c|c|c|}
\hline \multirow[b]{3}{*}{$\begin{array}{l}\text { Grass genotypes or } \\
\text { herbicide treatment }\end{array}$} & \multicolumn{9}{|c|}{ Yield $^{\mathrm{a}}$ (kg/ha) } & \multirow{2}{*}{\multicolumn{3}{|c|}{$\begin{array}{l}\text { Proportion leafy } \\
\text { spurge }^{c} \%\end{array}$}} \\
\hline & \multicolumn{3}{|c|}{ Grass } & \multicolumn{3}{|c|}{ Leafy spurge } & \multicolumn{3}{|c|}{ Total $^{\text {b }}$} & & & \\
\hline & 1994 & 1995 & 1996 & 1994 & 1995 & 1996 & 1994 & 1995 & 1996 & 1994 & 1995 & 1996 \\
\hline Rebound smooth brome & 975 & 2,880 & 1,585 & 5 & 150 & 60 & 1,200 & 3,470 & 2,040 & 0.5 & 4 & 3 \\
\hline Rodan western wheatgrass & 809 & 1,790 & 370 & 20 & 235 & 180 & 1,015 & 3,220 & 1,550 & 3 & 7 & 12 \\
\hline Bozoiskv Russian wildrye & 435 & 900 & 290 & 25 & 280 & 160 & 680 & 2,390 & 1,100 & 4 & 12 & 15 \\
\hline Arthur Dahurian wildrye & 2,705 & 3.235 & 235 & 5 & 120 & 195 & 2,870 & 4,540 & 1,175 & 0.1 & 3 & 17 \\
\hline Mankota Russian wildrye & 480 & 850 & 130 & 15 & 190 & 175 & 690 & 2,185 & 1,245 & 3 & 9 & 14 \\
\hline $\begin{array}{l}\text { Reliant intermediate } \\
\text { wheatgrass }\end{array}$ & 1,775 & 2,740 & 1,270 & 10 & 120 & 65 & 1,920 & 3,565 & 1,845 & 0.5 & 3 & 4 \\
\hline Hycrest crested wheatgrass & 1,530 & 2,715 & 820 & 15 & 300 & 160 & 1,610 & 3,530 & 1,525 & 1 & 9 & 11 \\
\hline Pryor slender wheatgrass & 1,440 & 1,310 & 10 & 20 & 330 & 220 & 1,575 & 3,020 & 1,185 & 1 & 11 & 19 \\
\hline Lodorm green needlegrass & 490 & 1,110 & 595 & 45 & 310 & 180 & 850 & 3,220 & 1,840 & 5 & 10 & 10 \\
\hline $\begin{array}{l}\text { Manska pubescent/ } \\
\text { wheatgrass }\end{array}$ & 1,700 & 3,170 & 1,130 & 10 & 150 & 80 & 1,860 & 3,955 & 1,660 & 0.5 & 4 & 5 \\
\hline Glyphosate $+2.4-\mathrm{D}^{\mathrm{d}}$ & 0 & 0 & 0 & 25 & 85 & 160 & 730 & 2,610 & 910 & 4 & 3 & 3 \\
\hline Control & 0 & 0 & 0 & 230 & 425 & 285 & 890 & 2,980 & 1,400 & 26 & 14 & 20 \\
\hline $\operatorname{LSD}(0.05)$ & 335 & 840 & 283 & 66 & 195 & 149 & 393 & 1,113 & NS & 6 & 6 & 2 \\
\hline
\end{tabular}

${ }^{\mathrm{a}}$ Four $0.25-\mathrm{m}^{2}$ quadrats harvested per plot in July each year.

${ }^{\mathrm{b}}$ Total yield includes weedy grasses and other forbs.

${ }^{c}$ Percent of component in total yield.

${ }^{\mathrm{d}}$ Glyphosate + 2.4-D applied annually at $0.4+0.65 \mathrm{~kg} /$ ha in June 1993, 1994, and 1995.

Arthur Dahurian wildrye produced the most herbage 1 year after seeding and averaged $2,705 \mathrm{~kg}$ a (Table 5). However, by 1996 production fell to only $235 \mathrm{~kg} / \mathrm{ha}$. Pryor slender wheatgrass production declined from $1,440 \mathrm{~kg} / \mathrm{ha}$ in 1994 to only $10 \mathrm{~kg} / \mathrm{ha}$ herbage production in 1996. Both Arthur Dahurian wildrye and Pryor slender wheatgrass are short-lived and decline quickly in productivity 3 or 4 years after seeding. These grasses have strong seedling vigor and establish readily. However, unless natural reseeding and 
establishment occurred, they would need to be reseeded every 4 to 5 years to provide long-term competition with leafy spurge.

Reliant intermediate wheatgrass and Manska pubescent wheatgrass yielded about $2,000 \mathrm{~kg} / \mathrm{ha}$ annually, which was the most consistent herbage production over the 3 -year period of the study (Table 5). Yield of all grass genotypes tended to decline in 1996 compared to 1995 . The annual precipitation was slightly above average, so moisture was not limited. However, there was only $3.3 \mathrm{~kg} / \mathrm{ha}$ available nitrogen in the soil. Also, the Kentucky bluegrass sod was beginning to reestablish, which created additional competition for nutrients and moisture with the seeded grass genotypes, thereby reducing overall productivity. Nitrogen fertilizer would have been required if the grasses were to continue to be competitive with leafy spurge.

Rebound smooth brome, Reliant intermediate wheatgrass, and Manska pubescent wheatgrass reduced the proportion of leafy spurge in 1996 to $5 \%$ or less of the total yield, which was similar to the herbicide treatment of glyphosate plus 2,4-D (Table 5). All grass treatments evaluated in 1996 reduced the leafy spurge yield proportion compared to the $20 \%$ found in the untreated control, except Pryor slender wheatgrass.

Based on both herbage production and leafy spurge competition, the best grasses to seed with conditions similar to Jamestown, ND, may be Manska pubescent wheatgrass or Reliant intermediate wheatgrass. Reliant intermediate wheatgrass was also very competitive at Fargo. Current nomenclature standards consider these two grasses to be the same species, Elytrigia intermedia (Host) Nevski. Reliant intermediate wheatgrass was released by the USDA in 1991 for its less spreading habit and increased compatibility with alfalfa (Medicago sativa L.) when used for hayland planting. Manska pubescent wheatgrass was released by the USDA in 1992 and is recognized for providing higher herbage quality and improved livestock gains compared to other varieties.

The best grass to plant to compete with leafy spurge will likely vary by location. For instance, Bozoisky Russian wildrye is very competitive with leafy spurge in Wyoming (Ferrell et al. 1992), but it was one of the least competitive species in these experiments. Within a location performance, variation among plant entries can generally be attributed to species differences rather than varietal differences. As observed at Jamestown, plant performance was very similar for the two varieties of Russian wildrye (Mankota and Bozoisky) and for the two varieties of pubescent/intermediate wheatgrass (Manska and Reliant).

Depending on the planned use of the area to be seeded, a native mixture of several species competitive with leafy spurge may be more appropriate as a rangeland seeding, whereas a single species often is preferred for pasture or hayland planting. In Minnesota the preferred mixtures all contained big and little bluestem. (Biesboer et al. 1993). In North Dakota, a good grazing mixture, competitive with leafy spurge, would appear to be western wheatgrass, green needlegrass, and slender wheatgrass. These species are highly compatible, establish rapidly, and generally provide good long-term productivity on a broad range of soils.

Page 9 of 10 


\section{Literature Cited}

Biesboer, D. D., W. L. Koukkari, and B. Darveaux. 1993. Controlling leafy spurge in Minnesota with competitive species and combined management practices. Proceedings of the Leafy Spurge Symposium. Fort Collins, CO: Colorado State University. 54 p.

Ferrell, M. A., T D. Whitson, D. W. Koch, and A. E. Gade. 1992. The control of leafy spurge (Euphorbia esula 1.) by the interaction of herbicides and perennial grasses. Research Progress Report. Western Society of Weed Science. pp. I-54-I-56.

Ferrell, M. A., T. D. Whitson, D. W. Koch, and A. E. Gade. 1993. Integrated control of leafy spurge (Euphorbia esula) with Bozoisky Russian wildrye (Psathyrostachys juncea) and Luna pubescent wheatgrass (Agropyron termedium var. trichophorum). Proc. West. Soc. Weed Sci. 46:36-38.

Lorenz, R. J. and R. G. Lym. 1993. A chronology of leafy spurge research. Proc. West. Soc. Weed Sci. 46:30-35.

Lym, R. G. 1994. Ecology, economic impact, and control of leafy spurge. West. Sec. Am. Soc. Anim. Sci. 45:111-114.

Selleck, G. W., R. T. Coupland, and C. Frankton. 1962. Leafy spurge in Saskatchewan. Ecol. Monogr. 32:1-29.

Wallander, R. T. and B. E. Olson. 1995. Enhancing the competitiveness of other species with leafy spurge. Proceedings of the Leafy Spurge Symposium. Fargo, ND: North Dakota State University. 40 p. 